\title{
Gauging the Evolution of Monetary Policy Communication Before and After the Financial Crisis
}

Kevin L. Kliesen, Business Economist and Research Officer

Brian Levine, Senior Research Associate

Christopher J. Waller, Executive Vice President and Director of Research

entral bank communication has come a long way since the Bank of England's policy (ostensibly) to "never explain, never apologize."1 Today, the refrain of central bankers might instead be "Can you hear me now?" The modern model of central bank communication suggests that central bankers prefer to err on the side of saying too much rather than too little. For example, in 2003, then-Fed Governor Janet Yellen said that the FOMC "had journeyed from 'never explain' to a point where sometimes the explanation is the policy." 2 The reason is that most central bankers believe that clear communication of monetary policy helps the Fed achieve its congressionally mandated goals of price stability, maximum employment, and stable long-term interest rates by reducing uncertainty about the direction of policy.

Central bank communication with the public takes many forms. These include the policy statements that many central banks release immediately after each meeting, press conferences, and speeches, interviews, and testimonies before governmental bodies. The Fed's principle medium of communication is the policy statement (press release) issued after each FOMC meeting. These post-meeting statements have evolved over time, particularly after the federal funds rate reached the zero lower bound (ZLB) on December 16, 2008. Prior to the Financial Crisis, the postmeeting statement mostly focused on the state of the economy and the Committee's rationale for raising or lowering the policy rate or explaining why the policy rate was not changed. In general, little was said about the future path of interest rate changes.

Fed communication eventually focused on influencing the public's expectations.

But as the U.S. economy transitioned from recession to a slower-than-average recovery, the Fed's communication policy approach changed. The new approach focused instead on influencing the public's expectations of the future direction and level of the federal funds target rate. This approach, in its current form, is referred to as forward guidance. ${ }^{3}$ Reflecting the evolution in central bank communication over this period, the average number of words in the postmeeting statement has increased over time. Prior to the

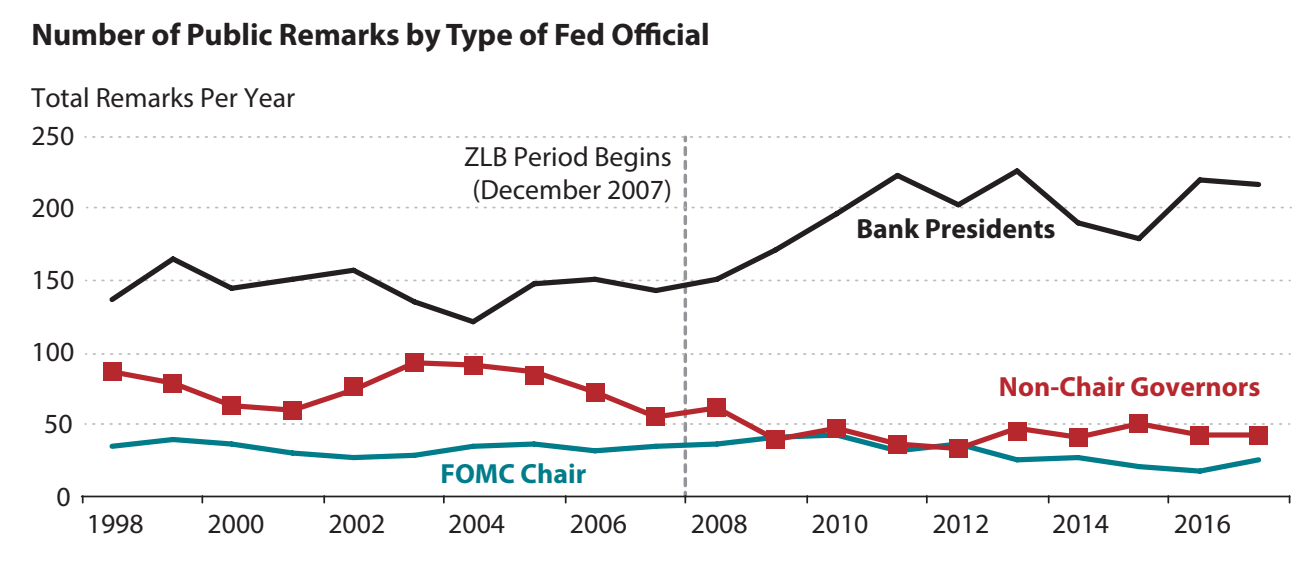

NOTE: Through 2017.

SOURCE: Board of Governors of the Federal Reserve System, the 12 Federal Reserve Banks, Bloomberg, and authors' calculations. 
ZLB period, statements had an average of 223 words. After the ZLB, the statement averaged 580 words, largely because of the adoption of complex quantitative easing (QE) policies and other unconventional policies that both increased the size of the balance sheet and changed its composition.

Fed officials have long used other forms of public communication to supplement policy statements. The figure reveals an unprecedented rate of communication with the public by Fed officials during the ZLB period. From 1998 to 2004, the total number of public remarks by Reserve Bank presidents remained roughly constant at about 150 per year. A different pattern occurred with governors and the Fed Chair. Beginning in 2005, the total number of public remarks by Reserve Bank presidents began to increase, reaching a peak in 2013 of a little more than 220 per year. Interestingly, though, the FOMC Chair and governors delivered public remarks slightly less frequently over the ZLB period. Admittedly, some of the reduced frequency of public remarks by members of the Board of Governors (excluding the Chair) reflects the fact that the Board has rarely operated with a full complement of seven governors.

Multiple simultaneous communication events by Fed presidents have also become more common over timeparticularly since the Financial Crisis. For example, in 2017, there were 60 days when more than one Reserve Bank president spoke. The number of days in 2004 was about half that. In contrast, in 2017, there were only three days when more than one Fed governor spoke publicly on the same day. This is down sharply from 2003, when there were 19 days on which multiple Fed governors spoke. As noted above, this decline in Fed governor communication reflects, to some extent, the smaller number of Fed governors in office.

\section{Notes}

1 Ahamed (2009, p. 371).

2 From a 2003 speech by Governor Yellen, as quoted in Holmes (2013).

3 Wynne (2013) documented that the Fed also used forward-looking language to shape expectations before the Financial Crisis. The FOMC's forward guidance policy was influenced importantly by Woodford (2001).

\section{REFERENCES}

Ahamed, Liaquat. Lords of Finance: The Bankers Who Broke the World. Penguin Books, 2009.

Holmes, Douglas R. Economy of Words: Communicative Imperatives in Central Banks. University of Chicago Press, 2013; https://doi.org/10.7208/chicago/9780226087764.001.0001.

Woodford, Michael. "Monetary Policy in the Information Economy." Presented at the Federal Reserve Bank of Kansas City, symposium "Economic Policy for the Information Economy," 2001;

https://www.kansascityfed.org/publicat/sympos/2001/papers/S02wood.pdf.

Wynne, Mark A. "A Short History of FOMC Communication." Federal Reserve Bank of Dallas Economic Letter, September 2013, 8(8);

https://www.dallasfed.org/research/eclett/2013/el1308.cfm\#n8. 